\title{
Beautiful Barriers: Art and Identity along a Belfast 'Peace' Wall
}

\author{
By Bryanna T. Hocking (Queen's University Belfast)
}

This article explores representational implications of an ongoing project along Belfast's main peace wall to transform the loyalist side of the barrier into an outdoor art gallery. Drawing in part on the interplay between social production and social construction (Low 2000) in the analysis of public space, the wall's art is assessed as one means through which both elites and non-elites inscribe meaning in the landscape. Particular attention is focused on a recently added mural created as part of a European Union-funded initiative to promote 'shared cultural space', and the identity this promotes for the local population. Using ethnographic data gathered through participant observation as well as interviews with policymakers, artists, community stakeholders and residents, I suggest that, while the wall's art is not necessarily received or experienced by the Protestant community in the manner it is intended, it broadly serves as a touchstone by which narratives of conflict and communal ties are activated and the neighbourhood's evolving identity as an element in a new touristoriented economy is brought to the fore.

\section{Introduction: From Icon of Division to Art Gallery of Protestant Heritage and Culture}

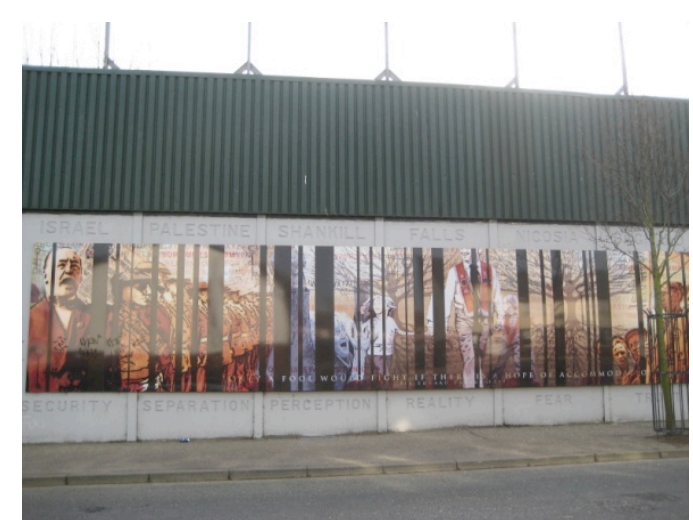

In the spring of 2009, three artworks funded by Northern Ireland's Department of Arts, Culture and Leisure were unveiled along Belfast's oldest and most imposing security barrier. Mounted on the Cupar Way peace wall in West Belfast, the art appeared on the Protestant side of the eight-metre high concrete and corrugated iron partition, which stretches for 650 metres and roughly separates the Shankill neighbourhood from the Catholic Falls Road. The project was commissioned by the Greater Shankill Partnership, a regeneration group aiming to create an outdoor art gallery and provide a platform for the heritage and culture of the area's Protestant residents. These initial pieces highlighted twentieth-century Shankill Road home life and military service, themes of history, division and reconciliation, references to traditional loyalist rituals such as bonfires, as well as personal reminiscences and hopes for the future alongside local residents' portraits (Greater Shankill Partnership 2009). 
Since then, three more artworks have been added as part of the 'If Walls Could Talk' project. These include: 'The Face', a metalwork relief meant to reflect the area's heritage as a key source of labour in Belfast's industrial past; 'Changing Faces', which focuses on the area as moving forward through images of old paramilitary murals juxtaposed with playful renderings of football players, good-looking girls and Union Jacks; and a multi-panel piece inspired by the work of the Northern Irish poet John Hewitt. Traditional graffiti artwork fills the spaces in between the publiclyfinanced panels.

This paper focuses on the effort to transform a marker of social division into a space for a positive representation of one of Belfast's toughest inner-city neighbourhoods. In it, I draw on Setha Low's (2000) concepts of 'social production' (the sum of forces shaping a space's actual 'physical creation') and 'social construction' (how people's spatial uses, interpretations, and associations produce meaning) to consider the impact of visual representation through public art for residents living in a socially marginalized, 'post-conflict' landscape. This dialogical approach, then, allows for an analysis of the space which considers people as 'social agents' who, like the capitalist state and its urban designers and bureaucrats, are intimately involved in the shaping of meaning for public spaces (Low 2000: 127-128). Thus, in addition to specific policy agendas addressing the wall and the subsequent artistic enhancements which have been carried out, people's memories of, and interactions with, the space offer insight into how imposed identities are embraced, reinterpreted and even rejected by local populations. Accordingly, the socio-economic-political processes which produced a mural in December 2010, related to the poet John Hewitt, who was born near the Shankill, will be the primary lens through which the social production of this space is explored. Interviews with residents are employed to consider the space's social construction. Whilst '[ $\mathrm{t}$ ] hose who create images stamp a collective identity' (Zukin 1995: 3), this article seeks to consider the myriad ways in which spaces of representation are experienced, contested, and even ignored by those they claim to make visible.

\section{The Cupar Way Peace Wall: History and Spatial Context}

Conceived in the darkest days of Northern Ireland's thirty-year conflict known as the Troubles, the first temporary barriers at Cupar Way were installed by the British Army after large-scale rioting between loyalists and republicans on 14 August 1969, led to the burning of homes on Bombay Street and in several other Catholic and nationalist areas in West Belfast (Macauley 2009). As sectarian violence in Northern Ireland persisted, the supposedly temporary divider was lengthened, heightened and rebuilt by the Northern Ireland Office using more permanent materials. Today, despite the existence of a peace agreement, the surrounding Shankill area continues to suffer from the presence of paramilitaries as well as high levels of unemployment and low percentages of residents with educational qualifications (Greater Shankill Partnership and Department for Social Development 2008).

The space across the road from the Cupar Way peace wall features a mix of private and public housing stock, a small locked memorial park to a young victim of suicide, a heavily fortified football pitch, and a large derelict field. The field is notable as the scene of an annual 11 July loyalist bonfire that marks the 1690 victory of the 
Protestant King William of Orange over the Catholic King James II at the Battle of the Boyne. During this annual ritual, effigies of the Pope and coffins draped in Irish tricolours have gone up in flames. More ordinary activity along the wall consists of vehicular traffic, dog-walking, occasional runners and low-intensity stone-throwing. But residents mostly assert that the primary use of the space is as a 'back road' to 'take traffic off the Shankill'. In contrast, on the Catholic side of the peace line, housing estates are built up against the wall, over which one may catch the occasional glimpse of a tricolour flapping in the breeze.

Against this backdrop, tourists - typically ferried there by the city's black taxis that offer conflict-based tours of working-class neighbourhoods - are a major presence. Numbers peak in the summer, when it is common to witness a cortege of hackney cabs idling along the wall. Drivers stand by with black pens so that their clients can add their mark to the countless cliché peace messages which have accumulated there since the 1998 multi-party peace agreement. Meanwhile, open-topped, double-decker tourist buses fly by, blaring their informational titbits into the atmosphere. In addition to the publicly-financed artworks on the wall, tourists can take in the unofficial art - a mix of cartoons, peace messages and standardized tagging, produced during international graffiti jam sessions and organized with help from an ex-loyalist paramilitary member and the ex-prisoners' association which employs him (Smith 2010a, 2010b). The graffiti does not have official permission to be placed on the wall, which is under the purview of Northern Ireland's Department of Justice, and a tense relationship exists between the organizers of the publicly-funded art - mounted on movable panels in the event that the wall is ever demolished - and those who spearhead the graffiti work. Both sides claim that the other's artistic product does not truly reflect the Shankill identity. While the precise politics of this relationship is beyond the scope of this article, it should be noted that the wall functions as a piece of contested territory with a variety of stakeholder groups laying claim to it, including some paramilitary and ex-paramilitary members (Smith 2010a, 2010b; Stewart 2010).

\section{Public Policy, Shared Space and Tourism along the Wall}

For post-conflict Belfast, the dozens of so-called 'peace' walls and other security barriers which criss-cross the city are perhaps the most troublesome reminder that Northern Irish society remains fundamentally divided. A number of government strategies $^{2}$ and funding schemes ${ }^{3}$ support the goals of expanding shared space and

\footnotetext{
${ }^{1}$ According to the ex-paramilitary member mentioned above, the competing visions for the wall emerged after an earlier joint effort to develop the wall foundered over money issues (Smith 2010a; Smith 2010b). The ex-paramilitary member categorized the graffiti art as more forward thinking, asserting that 'it's neutral' and 'doesn't take sides' (Smith 2010a). He dubbed the publicly-funded art 'demeaning' and disconnected from the life and history of the Shankill people (Smith 2010a). Meanwhile, a Greater Shankill Partnership official asserted that 'most of the community isn't necessarily so enthused about the tagging' (Small 2010), and a partnership board member went so far as to say the graffiti art was organized 'because he [saw] me as a threat or the partnership as a threat' (Stewart 2010). More generally, existing paramilitaries in the area have an interest in the symbolism appearing on the wall, and are consulted by the Greater Shankill Partnership when new images go up (Stewart 2010).

2 Among these documents are Belfast City Council's Good Relations Strategy (BCC 2003) and Peace and Reconciliation Action Plan (BCC 2010), and the Office of the First Minister and Deputy First Minister's A Shared Future (OFMDFM 2005) and draft Cohesion, Sharing, and Integration document
} 
improved relations between previously conflicted communities in hopes of removing the peace lines. But, despite these public policy aspirations, the city's current tourism strategy seeks to capitalize on the walls' presence, casting the walls and the 'outdoor gallery of world-class art works' at Cupar Way as a key attraction in a landscape where 'memory of the recent conflict is never far away' (Belfast City Council and Northern Ireland Tourist Board 2011: 13). As Wiedenhoft Murphy (2010: 543-544) notes in her work on the development of the tourist industry in West Belfast, 'the [peace] lines have become one of the "sites" that local and citywide tour guides include in their itineraries to visibly express that the peace process is still being negotiated', with ex-paramilitary prisoner groups on both sides of the sectarian divide forging partnerships to cash in on the tourist demand to consume these former zones of conflict (Ibid.: 555). The art, then, feeds into the Northern Ireland tourist machine, which has been promoted by European Union peace monies, and into the identity this industry projects for the area and its residents.

\section{Case Study: The John Hewitt Mural}

'It's transforming that space and in transforming that space you are giving it another expression... I think it's a valid and useful and interesting expression of people in that particular area who need to feel comfortable in their own identity and their own background, comfortable in saying that this is who we are and using that as a basis to have the confidence to reach out to other communities.' (Pat Colgan (2011), chief executive, Special EU Programmes Body)

The recently completed 'Hewitt in the Frame' mural reflects the competing policy goals shaping the state's relationship to the wall. It also elucidates how state-financed images of community identity, often produced in tandem with small numbers of handpicked community groups, are promoted, contested, and internalized in a given public space. Funded by the European Union's PEACE III programme, the Hewitt mural was carried out as part of Belfast City Council's Creative Legacies initiative, which

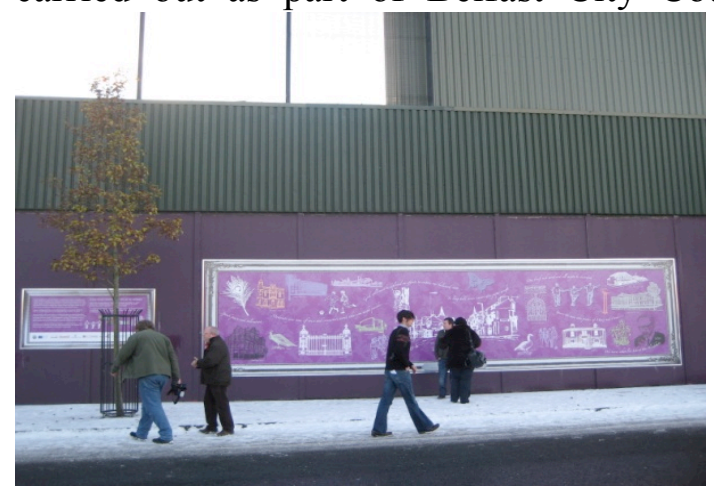
supported locally-proposed public art projects in an effort to encourage the growth of 'shared cultural space' in some of Belfast's toughest inner-city neighbourhoods (BCC 2011). In this instance, the Greater Shankill Partnership teamed with the high-profile East Belfast artist collective Creative Exchange. Creative Exchange, in turn, worked with youth and community groups as well as

(OFMDFM 2010). However, recent surveys show that the majority of residents oppose taking the walls down (US-Ireland Alliance 2008).

${ }^{3}$ Since 1995, the European Union has funded peace and reconciliation programmes for Northern Ireland and the Border Counties of Ireland through its PEACE I, PEACE II and PEACE III programmes (Special EU Programmes Body 2007). In January 2012, the International Fund for Ireland announced the launch of a $£ 2$ million programme for confidence and relationship building initiatives aimed at bringing about the conditions that would lead to the removal of security barriers in Northern Ireland (BBC News Online 2012). 
primary schools in the Shankill area, to carry out art and poetry workshops. The intent was for Creative Exchange artists to make a Hewitt-themed, multi-panel mural, which would contribute to the 'vibrant expression of the Shankill and its people' on the wall, highlight 'local hero' Hewitt (BCC 2011: 8) as an inspirational role model for the community, enhance confidence for workshop participants, and also provide a framed space for people ${ }^{4}$ to sign their names (Small 2010). ${ }^{5}$

Over a two-month period in the spring of 2010, I observed two of these workshops one with a youth club from the upper Shankill, the Glencairn Youth Initiative, and another with young men from a local training programme located on Lanark Way, just around the corner from the peace wall. I also interviewed members of Families Beyond Conflict, a community development group which took part in workshops, and sat in on one primary school poetry session. The youth workshops, like the PEACE III programme that funded them, were notable for their emphasis on promoting a positive city and neighbourhood image, and for their reinforcement of anti-sectarian themes and imagery. ${ }^{6}$ From the outset, a more pedagogical tone predominated in the Glencairn youth workshops, which were attended by about a dozen teenagers between the ages of thirteen and fifteen. There were field trips to the wall ${ }^{7}$ and discussions about the Shankill's attributes as well as about the peace process. Meanwhile, sessions with the school-leavers' training group, which consisted of roughly five teenage males, were less didactic. The boys sometimes wandered off to play pool or smoke, leaving the instructor to finish the art projects, which included gluing bottle caps onto large stencilled letters. Hewitt and his poetry were mentioned mostly in passing, with the bulk of the time in the youth workshops spent on hands-on art projects. On one occasion, the instructor told the Glencairn group she had decided against showing them a DVD about the poet because it was 'a wee bit boring' (personal observation, 19 May 2010), while another instructor, brought in to lead a writing workshop, later told that same group that Hewitt's work 'was not the sort of poetry you would probably read', although she did give them a brief overview of his life and work (personal observation, 26 May 2010). ${ }^{8}$

\footnotetext{
${ }^{4}$ The tourist audience is a key component in shaping the meaning of many public spaces in Belfast. For instance, in addition to the Hewitt mural, the Creative Legacies programme funded an abstract gateway sculpture, known as the 'Angel of the Road', for the Lower Shankill Road. At the unveiling, the local city councillor deemed this an important step in establishing the 'Shankill Quarter', one of the emerging 'place destinations' envisaged in Belfast's latest tourist strategy (BCC and NITB, 2011).

5 The Greater Shankill Partnership has waged a losing battle to make the black taxi drivers refrain from encouraging their passengers to sign the artworks. In mid-2011, signs forbidding writing on the artworks were added to at least three pieces, but this does not appear to have stopped the activity. ${ }^{6}$ At times, it was unclear precisely what constituted appropriate imagery for the wall. One instructor/artist said there was 'just no way' she would include the paramilitary drawings some of the youths created (Cherry 2011), and another said she 'didn't want anything on that that was going to be offensive to anybody' (Robb 2011). However, an image of a poppy, associated with the British military and, therefore, contentious in Northern Ireland, was included due to its 'cultural' import and presence on the Lower Shankill Road, which needed to be represented in the piece (Robb 2011). The Shankill Road has suffered from a fractured identity due to intra-loyalist paramilitary feuding, and there were concerns that the mural should depict aspects of the road in its entirety.

${ }^{7}$ During one of the field trips to see the wall, the instructor/artist, a former city council aide, told the youths that 'the graffiti doesn't really work', and noted that they were 'eventually going to have a lot of murals along here' (personal observation, 5 May 2010).

${ }^{8}$ In contrast, according to participants, the poetry/art workshops for the adult Families Beyond Conflict members included a significant focus on Hewitt and his work (Bailey 2011; Bell 2011). Praising the project, one participant, who was previously unaware of Hewitt's Shankill connection, noted: 'Tourists
} 
During the process, the Hewitt artwork had to expand in size to include additional panels - featuring photographic images of some of the 'community' artwork - as workshop participants insisted that their artistic creations be included in, as opposed to merely influencing, the final project as was initially envisaged (Small 2010; Robb 2011). Before one meeting, the director of the upper Shankill youth club confronted the artist/instructor about precisely how Glencairn would be represented and demanded that the 'actual piece' include their work (personal observation, 19 May 2010). Throughout the Glencairn workshops, the identity promoted for the artwork and the identity the youths wanted to depict in their art projects was episodically at odds. For instance, the instructor told the youths: 'we are trying not to do flags.' When one girl persisted, the instructor then took a sharper line: 'We are not doing the Union Jack. We are doing things celebrating the Shankill' (personal observation, 12 May 2010). On another occasion, the Glencairn youths were told 'nothing negative, nothing sectarian' and dissuaded from depicting the Union Jack in their artwork, but they were encouraged to paint emblems such as peace symbols (personal observation, 26 May 2010). ${ }^{9}$ In perhaps the most heated moment of the project, the instructor attempted to lead the youths in rewriting a poem they had worked on about identity and the wall using text message shorthand - but the kids, at the urging of one of the club's staff members, resisted, agreeing with the staff member that to put such work on the wall would make them and their community look 'stupid' - and the idea was dropped (personal observation, 2 June 2010).

The Hewitt mural was unveiled on a bright snowy morning in early December 2010 . In addition to the panel of community artwork, the piece included artist-created sketches of Shankill Road life and landmarks accompanied by Hewitt poetry, a panel of the kids' poetry, a framed blank space in which to sign one's name, and an informational board explaining the project and asking that visitors refrain from

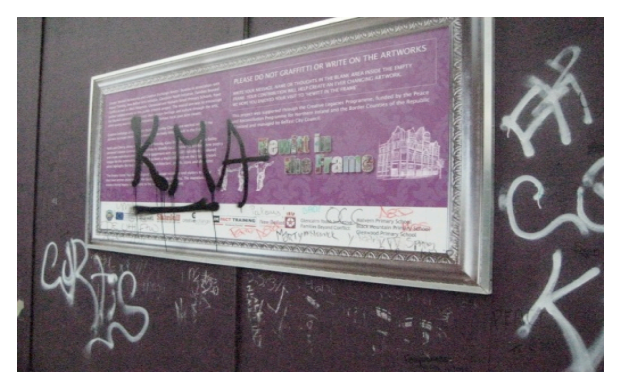
writing on the art. The unveiling was sparsely attended (roughly two dozen people were present) and consisted mainly of individuals affiliated with the project or city council aides (personal observation, 7 December 2010). Of the more than a dozen residents who lived near the peace wall and were subsequently interviewed ${ }^{10}$, none reported being invited to the event, despite repeated assertions at the unveiling that it was fundamentally a 'community' project.

are going to learn about John Hewitt... There's famous people that come from here. It's not all doom and gloom' (Bailey 2011).

9 Throughout 'the Troubles' and beyond, Northern Ireland's landscape has been shaped by the enduring tensions between its two dominant ethnic groups: Catholic nationalist republicans who historically have favoured unification with the Irish Republic and Protestant unionist loyalists who assert that Northern Ireland should remain a part of the United Kingdom. In this context, the Union Jack is often perceived as a Protestant marker of identity and is widely displayed in working-class loyalist neighbourhoods, particularly during key times in their commemorative calendar such as the anniversary of the Battle of the Boyne. Thus, whilst many of the youths would have seen the flag as a ubiquitous feature of the Shankill Road - one girl showed up to the sessions with a Union Jack temporarily tattooed on her left hand - the instructor said she chose not to allow Union Jacks in the art because the wall was being developed as part of 'cultural tourism' and therefore a message of 'tribalism' was not acceptable (Robb 2011).

${ }^{10}$ All Shankill Road residents quoted in this paper were interviewed on 5 October 2011, 6 October 2011, 7 October 2011, 11 October 2011, and 18 October 2011. 
And while the Hewitt mural is an attractive addition to the wall, it is difficult to assess whether it contributed to a 'shared cultural space' (BCC 2011) as suggested by the funding programme or is embraced by the wider 'community' (the Greater Shankill has a population of more than 20,000). Within months, it, too, had been graffitied. By April 2011, the sinister imperative - 'Kill Republicans' - appeared spray-painted in large letters further down along this same peace wall, thus raising persistent questions about the overall sharedness of this space.

\section{Residents and the Artistic Divide}

As part of this research, I conducted more than a dozen in-depth interviews with residents in October 2011 who lived in proximity to the loyalist side of the Cupar Way peace wall. In an effort to identify residents who would be most likely to have some familiarity with the art, I mainly chose to interview those who could see the art from their windows or from outside their front door. A handful of individuals were also interviewed at a church community centre which looked out on the wall. All identified as either being from, or part of, the Shankill's Protestant community, though a small minority said they no longer ascribed to any identity or considered themselves simply Northern Irish, and one man said his identity as a Christian subsumed previously-held associations. The intent was to discuss residents' lives, the peace wall and their response to the addition of the artworks, including the artworks' claims to represent Protestant culture and create a 'positive' image for the area, thereby potentially transforming perceptions of the space.

Opinion was nearly evenly split as to whether the art was beneficial. However, few research participants had a clear sense of what the art was about or what it was meant to accomplish, apart from a possible means to counteract the 'rude and bad things' that had been written on the wall over the years. Several pointed out that they were not consulted or notified when new works went up. There was also a significant reticence to participate in interviews, with requests to talk about the art often brushed off with the response that the resident 'never looked at it' or '[didn't] go near it'. Assertions that the art was a 'waste of money' were also common. Strikingly, few of the residents who did agree to sit for interviews saw their identity reflected in the art, though more than one said it generally represented the community's history, and one single mother said she believed the art was a statement that we 'just want to live in peace.'

For others, the wall and the conflict were inseparably linked, a factor the presence of art there, in their view, did nothing to ameliorate. One twenty-nine-year-old man who lives directly across the street from it said he was planning on moving because 'it's not nice to look at it... I didn't think it would bother me. But it has now.' While the violence at the wall was limited to kids throwing occasional stones, he said, the lingering fear 'that something' could come across the wall and land in his front room was ever-present - a threat the art, which he dubbed an 'eyesore', could not diminish. For other residents, mentions of the wall brought back memories of childhood rioting and of being 'chased by the peelers', of the British soldiers stationed at a base and lookout along the wall during the Troubles, of a now-demolished pub frequented by the infamous Shankill Butchers murder gang, and of feeling cut off from former friends and family who lived in the Catholic community on the other side 
of the wall. ${ }^{11}$ For others still, discussing the wall and its art was a means to assert their open-mindedness or hospitality by invoking friendships with Catholics or noting their willingness to show tourists around.

Increased visibility in the symbolic landscape did not appear to be a concern of these residents. One elderly disabled man, a member of the loyalist Ulster Volunteer Force for forty years, summed up the wall and its art as 'part of the furniture. It's there, but it's not there.' As such, the symbolism of the art was of no importance to him, 'provided it's not republican.' Similarly, a teenage mother, whose kitchen window framed some of the panels, said the art 'doesn't annoy me' as long as it did not represent the loyalist community as 'scumbags'. But she maintained that the art 'didn't change anything,' and that the area was still under paramilitary control ${ }^{12}$ to such a degree that her ex-boyfriend, a Catholic, was not free to visit their daughter there. Even among those who felt the art was a positive addition, the colour or the fact that the art made the wall 'less scary' or 'more inviting' were the most frequently cited reasons for liking it. A few, including one Scottish resident who said he felt the art represented the city as 'up and coming,' situated it in a broader civic context. Interestingly, one elderly housebound woman found the activity the art attracted, not the art itself or the identity it projected, most appealing. She viewed the stream of tour buses and black taxis passing by her front window as a form of entertainment, helping to break up the monotony of her days. 'It's lovely to see it all. It gives me something to look at,' she said.

Overall, specific pieces of art on the wall were rarely mentioned, a factor which suggests that for most research participants the cacophony of images present there from the publicly-funded artistic panels to the graffiti art to the tourist signatures had become blurred and confused in memory. Even so, a vague perception that the wall art was about peace existed. This factor, given the stated lack of engagement with the art, is likely attributable to a combination of media messaging and the countless words of peace covering both the wall (and its art). Questions about the Hewitt mural elicited mainly non-recognition. Even the few who claimed to have heard the name were unaware that he had been a poet and that a mural related to Hewitt's work had been added to the wall within the past year. Moreover, those who could point to an artwork they particularly liked, sometimes referenced images that did not actually appear on the wall. For instance, one man took me down to the wall to show me a picture of his niece which was not there, and another woman said she liked 'Nelson Mandela's one', which does not appear on this peace wall, though an image of the South African leader is included on a different barrier on the Catholic side of the wall. Their confusion may be due in part to the manner in which most of these residents said they experienced the space - driving in their car - as well as to the sheer quantity of murals in West Belfast.

\footnotetext{
${ }^{11}$ The gates at each end of the Cupar Way peace wall are opened to traffic and pedestrians during the day, but are closed at night (Northern Ireland Department of Justice official, 26 August 2010, email message to author).

${ }^{12}$ Along these lines, one artist involved in the Hewitt mural said that UVF paramilitary members were consulted as to whether any of the symbolism included in the final project could 'inadvertently' contribute to contentious conditions (Robb 2011).
} 


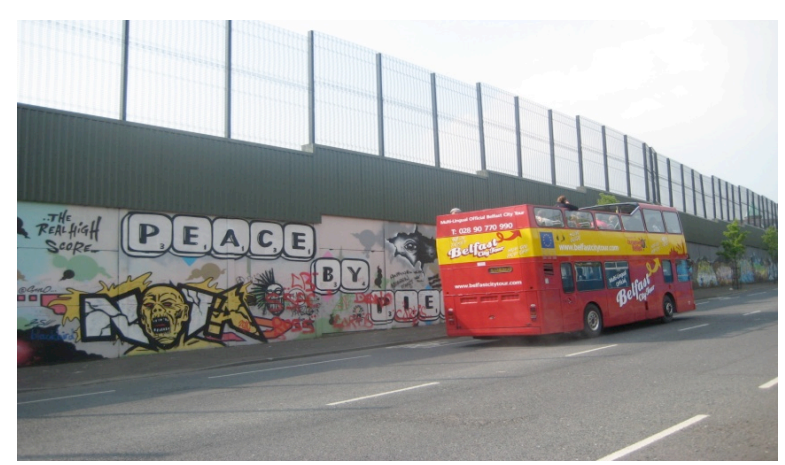

Furthermore, the perception that the primary intended audience for the art was tourists, not the community, was widely held. Reactions to this influx, however, were mixed, with some pronouncing it 'a good thing' for the area and others expressing annoyance or feelings of objectification by the 'tourist gaze' (Urry 1990). In this way, the art appears to contribute to a new identity for Shankill residents at large, that of de facto tourist attraction. Embedded as it is within a broader tourist context, which itself requires a degree of 'performativity' from residents, the art functions in part as a shaper of identity rather than mere representation of identity. One youth worker, a former Ulster Defence Association prisoner called Ticker, expressed his own mixed emotions to the tourist presence. He asserted it made him 'feel like a goldfish in a bowl'. Whilst he was proud of his role in the conflict and what he has accomplished for his community, he wondered if the tourists are 'looking at me as if I'm some sort of animal in a cage'. For others, the tourism that the art is in part aimed at attracting only accentuated preexisting negative stereotypes. Lisa recounted how visiting Canadians asked her where they could pay money to see the murals along the peace wall. 'Back home they had been told people were standing on the corner taking protection money to look at the murals... They thought they were entering a war zone', she noted. As for the art itself, 'it just makes it more run-down,' said another man. 'Graffiti is associated with youth crime. Tourists come and see Northern Ireland and think it is backward'. Though this same man saw the publicly-financed art as preferable, he asserted that the lack of continuity between panels (and what he considered insufficient information about why they were there), as well as the official art's relatively sparse presence compared to the more ubiquitous graffiti art, negated any potential benefits. Suggestions that the art could contribute to making the space around the wall more shared (other than as a tourist curiosity or as a thoroughfare for traffic from both sides) were mostly rejected. Some residents said it was a space they avoided or told their children to avoid. And one male pensioner harrumphed, 'You won't get a Catholic walking up this street'.

Strikingly, a rumoured visit by the pop star Rihanna, who was in town to film a music video and give a concert in September 2011, prompted one of the strongest reported communal presences at the wall. According to several residents, within minutes of word of her impending visit appearing on the Facebook and Twitter accounts of local Shankill youths, hundreds if not thousands of community members congregated along the wall with autograph books and camera phones in hand. In this way, the wall took on added layers of significance, as its appeal was briefly elevated in the eyes of residents to the status of global icon worthy of a pop star's attention. The status conveyed on the wall by Rihanna's rumoured - and unrealized - visit galvanized residents to turn out to gawk at the famous gawker. In this way, it transformed them into both tourists and potential objects of tourism without ever having to leave their own neighbourhood. 


\section{Conclusion: A Positive Identity for Whom? The Limitations of Visual Representation}

The ongoing effort to create a positive identity for the Shankill community along the Cupar Way peace wall through the addition of artworks raises important questions about the effect of state - or elite-imposed communal identities, and their reception by those whose culture they claim to make visible. As this article notes, the 'social

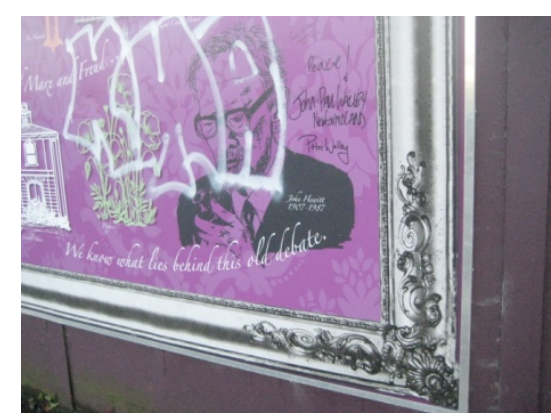
production' of the space through art is not necessarily received or experienced by the adjacent Protestant population in the manner it is intended. Instead, interviews with residents reveal a space whose 'social construction' is fluid and far from fixed. Nevertheless, the art and its backdrop broadly serve as a mnemonic by which individual narratives of conflict and communal pride are activated. As such, it plays a role in revealing residents' depth of identification with the Shankill Road, though the art does not appear to wield much emotional power or connection with those who live near it. Indeed, the overarching response to the intended transformation of the wall into art gallery was to ignore it. Moreover, the degree of pejorative, non-tourist graffiti on the artworks suggests the use of defacement by some community members as one 'tactic' of resistance (de Certeau 1984) to the identity that is projected there.

The obvious correlation between the neighbourhood's evolution as an element in Belfast's post-conflict tourist push and the state's incentive to fund artworks at the wall underscores the importance of globalization and economic imperatives in shaping local place identities. But the effort to paint a palatable (and consumable) image of a neighbourhood whose name became synonymous with conflict during the Troubles inevitably risks embracing a homogenized and fixed identity for the area. While further opening the space to global tourist traffic, the effort potentially reenforces the very divisions the art claims to counteract by marking the space as officially Protestant. This raises the question: precisely for whom is the 'positive' Protestant identity being created? What are the limits of visibility? And does inclusion in a symbolic landscape forged by state-financed public art programmes allow residents to transcend the 'troubled' past and embrace a future suitable for more than 'cultural tourism' purposes? The data presented here says as much about what visibility forecloses - in the case of the Hewitt mural, references to the Union Jack as to what it opens up. Whether the art is helping turn 'a destructive force into a vibrant expression of the Shankill and its people', as boasted by the official programme booklet, is debatable. Clearly, opinion is divided on the ground, a disjunction that is overlooked in the state's effort to overcome past conflict through self-defined 'positive' statements about the future.

Finally, the apparent lack of identification with the art is hardly surprising given the relatively thin community involvement in the project to date and residents' consistent assertions that it is actually intended for visitors. Whilst most of those interviewed seemed broadly satisfied to cede the area along the wall to the international tourist market, the neighbourhood's tourist appeal and the implications this has for its people's identity elicited ambivalent responses and remains a topic for additional 
investigation. The art can be a point of optimism for some who felt it showed the community as moving toward a peaceful future. But for others, the works only further ghettoized the area rather than facilitate normalization. Such findings suggest the limited potential of visual representations to adequately address the multivocal and hybrid identities present in any locality, and the need for broader, more resource intensive engagement processes if such efforts are attempted.

\section{About the author}

Bryanna T. Hocking is a PhD candidate in Irish Studies at Queen's University Belfast. Her research interests include Northern Ireland, public space, public art, symbolic landscapes, spatial identities and post-conflict urban cultures.

\section{Bibliography}

BBC News Online (2012), ‘ $£ 2 m$ Project Aims to Remove Northern Ireland Peace Walls', 18 January, http://www.bbc.co.uk/news/uk-northern-ireland-16603481 (accessed 20 January 2012).

Belfast City Council (2003), Good Relations Strategy: Building Our Future Together, Belfast: Belfast City Council.

http://www.belfastcity.gov.uk/publications/GoodRelationsStrategy.pdf (accessed 31 May 2010).

----- (2010), PEACE III: Phase II of the Belfast Peace and Reconciliation Action Plan 2011-2013. Belfast: European Union and Belfast City Council.

----- (2011), Creative Legacies: Enhanced Development and Outreach Programme, Belfast: Belfast City Council.

Belfast City Council and Northern Ireland Tourist Board (2011), Belfast Tourism: Gateway to the Future (An Integrated Strategic Framework for Belfast Tourism: 2010-2014), Belfast: Belfast City Council.

http://www.belfastcity.gov.uk/tourism/docs/tourismstrategy20112014.pdf (accessed 15 October 2011).

De Certeau, Michel (1984), The Practice of Everyday Life, Berkeley: University of California Press.

Greater Shankill Partnership (2009), If Walls Could Talk, Belfast: Greater Shankill Partnership.

Greater Shankill Partnership and Department for Social Development (2008), Greater Shankill: Strategic Regeneration Framework, Belfast: Greater Shankill Partnership and Department for Social Development.

http://greatershankillpartnership.org/attachments/article/37/SRF.pdf (accessed 20 October 2011).

Low, Setha (2000), On the Plaza: The Politics of Public Space and Culture, Austin: University of Texas Press.

Macauley, Conor (2009), 'Burning of Bombay St: 40 Years On', BBC News Online. 14 August. http://news.bbc.co.uk/1/hi/northern_ireland/8198725.stm (accessed 4 September 2010).

Office of the First Minister and Deputy First Minister (2005), A Shared Future:

Policy and Strategic Framework for Good Relations in Northern Ireland, Belfast: OFMDFM. http://www.asharedfutureni.gov.uk/policy-strategic.pdf (accessed 25 January 2010). 
http://www.nidirect.gov.uk/reformatted_final_print_version_csi_-_26.07.10.pdf (accessed 5 August 2010).

Special EU Programmes Body (2007), 'SEUPB: What is the PEACE III Programme?' http://www.seupb.eu/programmes2007-2013/peaceiiiprogramme/overview.aspx (accessed 30 May 2010).

Urry, John (1990), The Tourist Gaze: Leisure and Travel in Contemporary Societies, London: Sage.

US-Ireland Alliance (2008), 'Belfast Residents Asked if Peacelines Should Come Down', http://www.us-

irelandalliance.org/content/155/en/About\%20the\%20Alliance/Press\%20Releases/200 8\%20Press\%20Releases/Peace\%20Poll\%20Results:\%20Belfast\%20Residents\%20As ked\%20if\%20Peace\%20Lines\%20Should\%20Come\%20Down.html (accessed 3 September 2010).

Wiedenhoft Murphy, Wendy Ann (2010), 'Touring the Troubles in West Belfast: Building Peace or Reproducing Conflict?', Peace \& Change 35 (4): 537-59. Zukin, Sharon (1995), The Cultures of Cities, Oxford: Blackwell.

\section{Interviews}

Bailey, S. 2011. Interview by author, Belfast, Northern Ireland, 19 April. Bell, J. 2011. Interview by author, Belfast, Northern Ireland, 19 April. Cherry, L. 2011. Interview by author, Belfast, Northern Ireland, 8 February. Colgan, P. 2011. Interview by author, Belfast, Northern Ireland, 14 February. Robb, D. 2011. Interview by author, Belfast, Northern Ireland, 9 June. Small, R. 2010. Interview by author, Belfast, Northern Ireland, 3 August.

Smith, W. 2010a. Interview by author, Belfast, Northern Ireland, 12 August. -----. 2010b. Interview by author, Belfast, Northern Ireland, 19 August.

Stewart, J. 2010. Interview by author, Belfast, Northern Ireland, 16 August. 